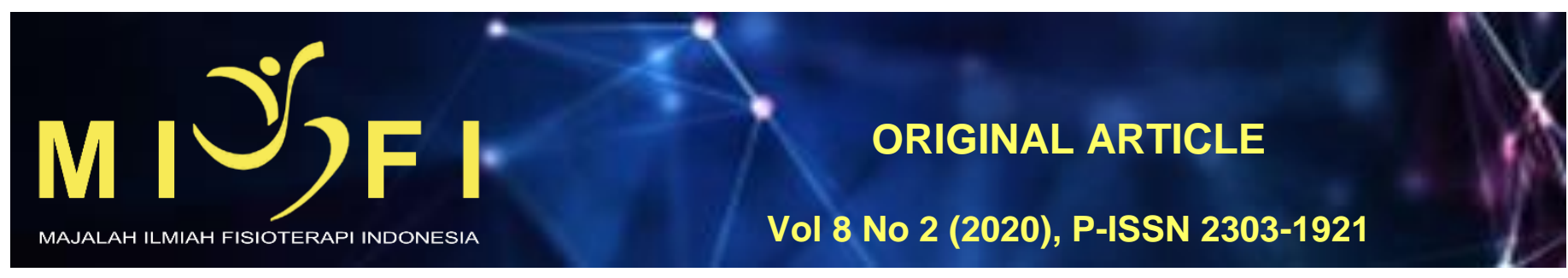

\title{
HUBUNGAN FAKTOR RISIKO ERGONOMI SAAT BEKERJA DENGAN KELUHAN MUSKULOSKELETAL PADA PENGRAJIN UKIRAN KAYU DI GIANYAR
}

\author{
Aryaning Dwi Antyesti ${ }^{1}$, Made Hendra Satria Nugraha ${ }^{2}$, I Putu Adiartha Griadhi ${ }^{3}$, \\ Ni Luh Putu Gita Karunia Saraswati² \\ ${ }_{1}^{1}$ Program Studi Sarjana Fisioterapi dan Profesi Fisioterapi, Fakultas Kedokteran Universitas Udayana \\ 2Departemen Fisioterapi, Fakultas Kedokteran Universitas Udayana \\ ${ }^{3}$ Departemen Fisiologi, Fakultas Kedokteran Universitas Udayana \\ aryaningdwiantyesti@gmail.com
}

\begin{abstract}
ABSTRAK
Pengrajin ukiran kayu merupakan salah satu pekerjaan yang mempunyai risiko mengalami keluhan muskuloskeletal. Hal ini dikarenakan postur pengrajin ukiran kayu sewaktu bekerja tidak ergonomis. Postur kerja yang tidak ergonomis ini, apabila dilakukan secara terus-menerus dan dalam jangka waktu yang lama maka dapat menimbulkan keluhan muskuloskeletal pada pengrajin ukiran kayu. Tujuan dari penelitian ini adalah untuk mengetahui hubungan faktor risiko ergonomi saat bekerja dengan keluhan muskuloskeletal pada pengrajin ukiran kayu di Gianyar. Penelitian ini merupakan penelitian observasional analitik dengan desain cross- sectional yang dilakukan pada bulan Maret-April 2019. Pengambilan sampel dilakukan dengan teknik Consecutive Sampling. Jumlah sampel penelitian ini sebanyak 96 orang. Variabel dependen yang diukur adalah keluhan muskuloskeletal menggunakan Cornell Musculoskeletal Discomfort Questionnaire (CMDQ). Variabel independen yang diukur adalah faktor risiko ergonomi saat bekerja menggunakan metode Baseline Risk Identification of Ergonomics Factor (BRIEF) Survey. Hasil analisis data menunjukkan bahwa adanya hubungan antara faktor risiko ergonomi saat bekerja dengan keluhan muskuloskeletal pada leher (nilai $p=0,035$ ), punggung atas (nilai $p=0,018$ ), punggung bawah (nilai $p=0,016$ ) serta tangan dan pergelangan tangan kanan (nilai $\mathrm{p}=0,001$ ).
\end{abstract}

Kata Kunci: Faktor Risiko Ergonomi, Keluhan Muskuloskeletal, Pengrajin Ukiran Kayu, BRIEF Survey, CMDQ

\section{RELATIONSHIP OF ERGONOMIC RISK FACTORS WHEN WORKING WITH MUSCULOSKELETAL DISORDERS IN WOOD CARVING CRAFTSMEN IN GIANYAR}

ABSTRACT
Wood carving craftsmen are one of the jobs that are at risk of developing musculoskeletal disorders. This is because the wood carving craftsmen's posture at work is not ergonomic. This non-ergonomic work posture, if carried out continuously and for a long time can cause musculoskeletal disorders in wood carving craftsmen. The purpose of this study was to determine the relationship of ergonomic risk factors when working with musculoskeletal disorders in woodcarving craftsmen in Gianyar. This study was an analytical observational study with a cross-sectional design which was done on March-April 2019. Sample technique used in this study is consecutive sampling. The total sample of this study was 96 people. The dependent variable is musculoskeletal disorders which was measured by the Cornell Musculoskeletal Discomfort Questionnaire (CMDQ). The independent variable is ergonomic risk factors when working which was measured by Baseline Risk Identification of Ergonomics Factor (BRIEF) Survey method. The results of this analysis showed that there was a relationship between ergonomic risk factors when working with musculoskeletal disorders of the neck $(p=0,035)$, upper back $(p=0,018)$, lower back $(p=0,016)$ and right wrist and hand $(p=0,001)$.

Keywords: Ergonomic Risk Factors, Musculoskeletal Disorders, Wood Carving Craftsmen, BRIEF Survey, CMDQ 


\section{PENDAHULUAN}

Indonesia merupakan negara yang memiliki beragam kesenian salah satunya adalah seni ukir. Seni ukir merupakan cabang dari seni kriya dimana dalam pengerjaannya seni ukir menggunakan alat pahat dan palu. Ukiran merupakan karya seni bangsa Indonesia yang sudah sepatutnya mendapat perhatian dan dilestarikan. Seorang pengrajin ukiran dapat berjam-jam lamanya duduk diam untuk dapat membuat sebuah ukiran kayu. Hal tersebut dapat menimbulkan berbagai keluhan pada pengrajin ukiran kayu, salah satunya yaitu keluhan muskuloskeletal.

Keluhan muskuloskeletal atau musculoskeletal disorders (MSDs) adalah keluhan pada bagian otot rangka. Keluhan muskuloskeletal ini umumnya dirasakan mulai dari keluhan yang sangat ringan hingga sangat sakit. Kerusakan pada sendi, ligamen, dan tendon dapat terjadi apabila otot menerima beban statis secara berulang dalam waktu yang lama1. WHO menyatakan bahwa kontribusi dari berbagai faktor risiko dapat menyebabkan gangguan muskuloskeletal dan juga memperberat gangguan ini.

Faktor biomekanika merupakan salah satu faktor risiko dari keluhan muskuloskeletal. Faktor ini meliputi posisi tubuh, force/beban, frekuensi, durasi, dan paparan pada getaran saat bekerja. Selain itu, faktor psikososial seperti gerakan kerja yang berulang, tuntutan performa kerja, lingkungan kerja yang terisolasi serta rendahnya hubungan antara pengawas dan pegawai ${ }^{2}$, dan faktor individu yang meliputi usia, jenis kelamin, indeks massa tubuh, kebiasaan merokok, kebiasaan olahraga dan masa kerja juga dapat menyebabkan keluhan muskuloskeletal ${ }^{3,4}$.

Menurut (Mayasari dan Saftarina, 2016) dalam dunia kerja aplikasi ergonomi sangat penting ${ }^{4}$. Ergonomi merupakan ilmu yang memanfaatkan informasi-informasi mengenai sifat, kemampuan dan keterbatasan manusia guna merancang suatu sistem kerja, sehingga orang dapat bekerja dengan efektif, aman dan nyaman ${ }^{5}$. Tidak hanya kenyamanan dan keamanan saja yang diperoleh pekerja dengan penerapan prinsip ergonomi, namun juga penyakit akibat kerja dan risiko dalam kecelakaaan kerja dapat menurun bahkan dapat meningkatkan produktivitas kerja ${ }^{4}$.

Menurut penelitian (Santosa dan Ariska, 2018) keluhan muskuloskeletal pada pekerja batik meningkat disebabkan oleh posisi kerja yang berisiko. Posisi kerja yang dimaksud yaitu yang menjauhi pusat gerak atau tidak dalam posisi netral. Hal tersebut memaksakan pekerja harus dalam posisi membungkuk seperti pada saat melakukan canting kain, pengecapan pada batik cap yang harus menjangkau semua bagian kain secara manual ${ }^{6}$.

Menurut hasil penelitian Jalajuwita dan Paskarini, 2015, ada hubungan yang kuat antara posisi kerja pekerja pengelasan dengan keluhan muskuloskeletal ${ }^{7}$. Postur tubuh yang tidak ergonomis pada saat bekerja, dimana pekerja pengelasan mayoritas bertumpu pada satu kaki dan jongkok yang terlalu lama, membungkuk dan posisi leher sering menghadap ke bawah dengan waktu yang lama adalah penyebab munculnya keluhan muskuloskeletal. Sikap kerja tidak alamiah ini pada umumnya terjadi karena karakteristik tuntutan tugas, alat kerja dan stasiun kerja tidak sesuai dengan kemampuan dan keterbatasan pekerja ${ }^{8}$.

Pada pengrajin ukiran kayu, keluhan muskuloskeletal dapat disebabkan oleh banyak hal. Hal yang paling berperan terhadap timbulnya keluhan muskuloskeletal adalah postur kerja pengrajin. Pengrajin ukiran kayu umumnya bekerja dengan posisi duduk, kaki dilipat, membungkuk dan sedikit menunduk. Hal tersebut sudah menjadi kebiasaan para pengrajin ukiran karena dengan posisi tersebut pengrajin menjadi lebih nyaman dalam bekerja9 .

Sikap kerja duduk di lantai dan membungkuk memiliki rerata total skor post yang lebih tinggi dibandingkan dengan bantuan meja dan kursi terhadap keluhan subjektif gangguan muskuloskeletal pada pengrajin ukiran kayu. Sikap kerja yang dipaksakan dan dikombinasikan dengan gerakan repetitif serta waktu yang lama inilah yang menyebabkan terjadinya keluhan muskuloskeletal pada pengrajin ukiran ${ }^{10}$.

Baseline Risk Identification of Ergonomics Factor (BRIEF) Survey adalah salah satu metode penilaian tingkat risiko ergonomi terhadap keluhan muskuloskeletal dengan menilai 4 faktor risiko yaitu postur, durasi, frekuensi dan beban kerja. Bagian tubuh yang dinilai dalam metode ini yaitu tangan dan pergelangannya, siku, bahu, leher, punggung dan kaki. Metode ini telah memenuhi syarat dan diakui oleh Occupational Safety and Health Administration (OSHA) dan telah banyak digunakan untuk penelitian ${ }^{11,12}$.

Cornell Musculoskeletal Discomfort Questionnaire (CMDQ) merupakan alat skrining keluhan muskuloskeletal. Kuesioner ini dikembangkan oleh Dr. Alan Edge dan mahasiswa ergonomi dari Cornell University. Validitas dari kuesioner ini telah diuji secara ekstensif oleh Dr. Oguzhan Erdinc di Turki dengan hasil yang baik dan validitas diagnostik survei ini dapat diuji dalam penelitian apa pun yang membandingkan respons survei dengan laporan klinis ${ }^{13}$.

\section{METODE PENELITIAN}

Penelitian ini adalah penelitian observasional analitik dengan desain cross-sectional (potong lintang). Penelitian ini dilakukan di tempat kerja pengrajin ukiran kayu di kabupaten Gianyar pada bulan Maret-April 2019. Sampel pada penelitian ini yaitu pengrajin ukiran kayu sejumlah 96 orang dengan teknik pegambilan sampel yaitu consecutive sampling. Kriteria inklusi pada penelitan ini yaitu berjenis kelamin laki-laki, berusia 35-60 tahun, bekerja 6-8 jam sehari, masa kerja minimal 1 tahun dan bersedia secara sukarela menjadi subyek penelitian dengan menandatangani informed consent.

Pada penelitian ini keluhan muskuloskeletal pada pengrajin ukiran kayu merupakan variabel dependen dan faktor risiko ergonomi saat bekerja merupakan variabel independen. Metode Baseline Risk Indentification of Ergonomics Factor (BRIEF) Survey digunakan untuk mengukur faktor risiko ergonomi saat bekerja dengan interpretasi rendah (skor 0-1), sedang (skor 2) dan tinggi (skor 3-4) sedangkan untuk mengukur keluhan muskuloskeletal digunakan metode cornell musculoskeletal discomfort questionnaire.

Data pada penelitian ini dianalisis dengan chi-square test dengan nilai $p>0,05$ untuk melihat apakah terdapat hubungan antara variabel independen dengan variabel dependen. Uji spearman's rho digunakan untuk melihat kekuatan hubungan antar kedua variabel. 
berikut.

Karakteristik responden pada penelitian ini berdasarkan umur, lama kerja dan masa kerja adalah sebagai

Tabel 1. Umur, lama kerja dan masa kerja responden.

\begin{tabular}{cccc}
\hline \multicolumn{2}{c}{ Variabel } & Frekuensi (f) & Persentase (\%) \\
\hline Umur & $35-47$ tahun & 63 & 65,6 \\
& $48-60$ tahun & 33 & 34,4 \\
Lama & 6 jam & 1 & 1,0 \\
Kerja & 7 jam & 13 & 13,5 \\
& 8 jam & 82 & 85,4 \\
Masa & $1-25$ tahun & 54 & 56,3 \\
Kerja & $>25$ tahun & 42 & 43,8 \\
\hline & Total & 96 & 100 \\
\hline
\end{tabular}

Tabel 1 menunjukkan bahwa responden terbanyak pada rentang umur 35 - 47 tahun yaitu sebanyak 63 responden atau $65,6 \%$ sedangkan pada umur $48-60$ tahun jumlah responden yaitu 33 responden atau $34,4 \%$. Lama kerja responden pada penelitian ini yaitu 6-8 jam dengan distribusi yaitu: lama kerja 6 jam sebanyak 1 responden atau $1,1 \%$, lama kerja 7 jam sebanyak 13 responden atau $13,5 \%$ dan lama kerja 8 jam sebanyak 82 responden atau $85,4 \%$. Masa kerja responden yaitu dengan masa kerja 1-25 tahun sebanyak 54 responden atau $56,2 \%$ dan masa kerja lebih dari 25 tahun yaitu sebanyak 42 responden atau $43,8 \%$.

Tabel 2. Faktor Risiko Ergonomi Saat Bekerja

\begin{tabular}{|c|c|c|c|}
\hline Risiko Ergonomi & & Frekuensi (f) & Persentase (\%) \\
\hline \multirow[t]{3}{*}{ Leher } & Rendah & 15 & 15,6 \\
\hline & Sedang & 37 & 38,5 \\
\hline & Tinggi & 44 & 45,8 \\
\hline \multirow[t]{3}{*}{ Punggung } & Rendah & 14 & 14,6 \\
\hline & Sedang & 34 & 35,4 \\
\hline & Tinggi & 48 & 50,0 \\
\hline Tangan dan & Rendah & 60 & 62,5 \\
\hline \multirow{2}{*}{ Pergelangan Tangan Kanan } & Sedang & 29 & 30,2 \\
\hline & Tinggi & 7 & 7,3 \\
\hline Tangan dan & Sedang & 53 & 55,2 \\
\hline Pergelangan Tangan Kiri & Tinggi & 43 & 44,8 \\
\hline \multirow[t]{3}{*}{ Bahu Kanan } & Rendah & 59 & 61,5 \\
\hline & Sedang & 19 & 19,8 \\
\hline & Tinggi & 18 & 18,8 \\
\hline \multirow[t]{2}{*}{ Bahu Kiri } & Rendah & 69 & 71,9 \\
\hline & Sedang & 27 & 28,1 \\
\hline \multirow[t]{3}{*}{ Siku Kanan } & Rendah & 57 & 59,4 \\
\hline & Sedang & 21 & 21,9 \\
\hline & Tinggi & 18 & 18,8 \\
\hline \multirow[t]{3}{*}{ Siku Kiri } & Rendah & 53 & 55,2 \\
\hline & Sedang & 31 & 32,3 \\
\hline & Tinggi & 12 & 12,5 \\
\hline Total & & 96 & 100 \\
\hline
\end{tabular}

Berdasarkan tabel 2 maka diketahui punggung memiliki tingkat risiko ergonomi tinggi terbanyak yaitu sebanyak 48 responden atau $50 \%$, tangan dan pergelangan tangan kiri memiliki tingkat risiko ergonomi sedang terbanyak yaitu 53 responden atau $55,2 \%$ dan yang memiliki risiko ergonomi rendah terbanyak yaitu bagian bahu kiri dengan jumlah responden 69 atau $71,9 \%$.

Tabel 3. Keluhan Muskuloskeletal

\begin{tabular}{|c|c|c|c|}
\hline \multirow{2}{*}{\multicolumn{2}{|c|}{ Bagian Tubuh }} & \multicolumn{2}{|c|}{ Keluhan Muskuloskeletal } \\
\hline & & Tidak Ada Keluhan & Ada Keluhan \\
\hline \multicolumn{2}{|l|}{ Leher } & $53(55,2 \%)$ & $43(44,8 \%)$ \\
\hline \multicolumn{2}{|l|}{ Punggung Atas } & $70(72,9 \%)$ & $26(27,1 \%)$ \\
\hline \multicolumn{2}{|l|}{ Punggung Bawah } & $29(30,2 \%)$ & $67(69,8 \%)$ \\
\hline \multirow[t]{2}{*}{ Pergelangan Tangan } & (Kanan) & $78(81,3 \%)$ & $18(18,8 \%)$ \\
\hline & (Kiri) & $78(81,3 \%)$ & $18(18,8 \%)$ \\
\hline \multirow[t]{2}{*}{ Bahu } & (Kanan) & $70(72,9 \%)$ & $26(27,1 \%)$ \\
\hline & (Kiri) & $78(81,3 \%)$ & $18(18,8 \%)$ \\
\hline \multirow[t]{2}{*}{ Lengan Atas } & (Kanan) & $68(70,8 \%)$ & $28(29,2 \%)$ \\
\hline & (Kiri) & $76(79,2 \%)$ & $20(20,8 \%)$ \\
\hline \multirow[t]{2}{*}{ Lengan Bawah } & (Kanan) & $69(71,9 \%)$ & $27(28,1 \%)$ \\
\hline & (Kiri) & $79(82,3 \%)$ & $17(17,7 \%)$ \\
\hline
\end{tabular}




\begin{tabular}{rcc}
\hline Panggul/ Pantat & $90(93,8 \%)$ & $6(6,3 \%)$ \\
\hline Total & $96(100 \%)$ \\
\hline
\end{tabular}

Berdasarkan tabel 3 dapat dilihat bahwa keluhan muskuloskeletal terbanyak yang dialami oleh pengrajin yaitu pada punggung bawah dengan jumlah 67 responden atau $69,8 \%$, kemudian keluhan pada leher sejumlah 43 responden atau $44,8 \%$ dan keluhan muskuloskeletal yang paling sedikit dialami oleh pengrajin yaitu pada panggul/pantat dengan jumlah responden yaitu sebanyak 6 responden atau $6,3 \%$.

\section{Uji Bivariat dengan Chi-Square Test dan Spearman's Rho}

Hasil uji korelasi faktor risiko ergonomi dan keluhan muskuloskeletal dapat dilihat pada tabel berikut.

Tabel 4. Tabel Silang Risiko Ergonomi dengan Keluhan Leher

\begin{tabular}{|c|c|c|c|c|c|c|}
\hline \multirow{2}{*}{ Variabel } & \multicolumn{3}{|c|}{ Keluhan pada Leher } & \multirow[b]{2}{*}{ Total } & \multirow[b]{2}{*}{$\mathbf{p}$} & \multirow[b]{2}{*}{ rs } \\
\hline & & Tidak Ada Keluhan & Ada Keluhan & & & \\
\hline \multirow{3}{*}{ Risiko Ergonomi } & Rendah & $10(66,7 \%)$ & $5(33,3 \%)$ & $15(100 \%)$ & \multirow{3}{*}{0,035} & \multirow{3}{*}{0,247} \\
\hline & Sedang & $25(67,6 \%)$ & $12(32,4 \%)$ & $37(100 \%)$ & & \\
\hline & Tinggi & $\frac{18(40,9 \%)}{53(552 \%)}$ & $26(59,1 \%)$ & $44(100 \%)$ & & \\
\hline
\end{tabular}

Pada tabel 4 responden yang mengalami keluhan muskuloskeletal leher terbanyak terdapat pada tingkat risiko ergonomi tinggi yaitu sebanyak 26 responden atau $59,1 \%$, selanjutnya responden yang tidak mengalami keluhan muskuloskeletal leher terbanyak terdapat pada tingkat risiko ergonomi sedang yaitu sebanyak 25 responden atau $67,6 \%$.

Tabel 5. Tabel Silang Risiko Ergonomi dengan Keluhan Punggung Atas

\begin{tabular}{|c|c|c|c|c|c|c|}
\hline \multirow{2}{*}{\multicolumn{2}{|c|}{ Variabel }} & \multicolumn{2}{|c|}{ Keluhan pada Punggung Atas } & \multirow{2}{*}{ Total } & \multirow[b]{2}{*}{$\mathbf{p}$} & \multirow{2}{*}{ rs } \\
\hline & & Tidak Ada Keluhan & Ada Keluhan & & & \\
\hline \multirow{3}{*}{ Risiko Ergonomi } & Rendah & $11(78,6 \%)$ & $3(21,4 \%)$ & $14(100 \%)$ & \multirow{4}{*}{0,018} & \multirow{4}{*}{0,246} \\
\hline & Sedang & $30(88,2 \%)$ & $4(11,8 \%)$ & 34 (100\%) & & \\
\hline & Tinggi & $29(60,4 \%)$ & $19(39,6 \%)$ & $48(100 \%)$ & & \\
\hline Total & & $70(72,9 \%)$ & $26(27,1 \%)$ & $96(100 \%)$ & & \\
\hline
\end{tabular}

Pada tabel 5 responden yang mengalami keluhan muskuloskeletal punggung atas terbanyak terdapat pada tingkat risiko ergonomi tinggi yaitu sebanyak 19 responden atau $39,6 \%$, selanjutnya responden yang tidak mengalami keluhan muskuloskeletal punggung atas terbanyak terdapat pada tingkat risiko ergonomi sedang yaitu sebanyak 30 responden atau $88,2 \%$.

Tabel 6. Tabel Silang Risiko Ergonomi dengan Keluhan pada Punggung Bawah

\begin{tabular}{|c|c|c|c|c|c|c|}
\hline \multirow[t]{2}{*}{ Variabel } & & \multicolumn{2}{|c|}{$\begin{array}{c}\text { Keluhan pada Punggung } \\
\text { Bawah } \\
\end{array}$} & \multirow[t]{2}{*}{ Total } & \multirow[t]{2}{*}{$\mathbf{p}$} & \multirow[t]{2}{*}{ rs } \\
\hline & & Tidak Ada Keluhan & Ada Keluhan & & & \\
\hline \multirow[b]{2}{*}{ Risiko Ergonomi } & Rendah & $8(57,1 \%)$ & $6(42,9 \%)$ & $14(100 \%)$ & \multirow{3}{*}{0,016} & \multirow{3}{*}{0,284} \\
\hline & Sedang & $12(35,3 \%)$ & $22(64,7 \%)$ & $34(100 \%)$ & & \\
\hline Total & & $29(30,2 \%)$ & $67(69,8 \%)$ & $96(100 \%)$ & & \\
\hline
\end{tabular}

Berdasarkan tabel 6 dapat dilihat responden yang mengalami keluhan muskuloskeletal punggung bawah terbanyak terdapat pada tingkat risiko ergonomi tinggi yaitu sebanyak 39 responden atau $81,2 \%$, selanjutnya responden yang tidak mengalami keluhan muskuloskeletal punggung bawah terbanyak terdapat pada tingkat risiko ergonomi sedang yaitu sebanyak 12 responden atau $35,3 \%$.

Tabel 7. Tabel Silang Risiko Ergonomi dengan Keluhan pada Pergelangan Tangan Kanan

\begin{tabular}{ccccccc}
\hline \multirow{2}{*}{ Variabel } & \multicolumn{2}{c}{ Keluhan pada Pergelangan Tangan Kanan } & \multirow{2}{*}{ Total } & \multirow{2}{*}{ p } & rs \\
\cline { 2 - 4 } & Tidak Ada Keluhan & Ada Keluhan & & \\
\cline { 1 - 5 } Risiko Ergonomi & Rendah & $55(91,7 \%)$ & $5(8,3 \%)$ & $60(100 \%)$ & & \\
& Sedang & $20(69,0 \%)$ & $9(31,0 \%)$ & $29(100 \%)$ & \multirow{2}{*}{0,001} & 0,396 \\
& Tinggi & $3(42,9 \%)$ & $4(57,1 \%)$ & $7(100 \%)$ & & \\
\hline \multicolumn{2}{c}{ Total } & $78(81,2 \%)$ & $18(18,8 \%)$ & $96(100 \%)$ & & \\
\hline
\end{tabular}

Berdasarkan tabel 7 responden yang mengalami keluhan muskuloskeletal tangan dan pergelangan tangan kanan terbanyak terdapat pada tingkat risiko ergonomi sedang yaitu sebanyak 9 responden atau $31,0 \%$, selanjutnya responden yang tidak mengalami keluhan muskuloskeletal terbanyak terdapat pada tingkat risiko ergonomi rendah yaitu sebanyak 55 responden atau $91,7 \%$.

Tabel 8. Tabel Silang Risiko Ergonomi dengan Keluhan pada Pergelangan Tangan Kiri

\begin{tabular}{ccccccc}
\hline \multirow{2}{*}{ Variabel } & \multicolumn{2}{c}{ Keluhan pada Pergelangan Tangan Kiri } & Total & p & rs \\
\cline { 2 - 5 } & Tidak Ada Keluhan & Ada Keluhan & & \\
\cline { 4 - 6 } Risiko & Sedang & $41(77,4 \%)$ & $12(22,6 \%)$ & $53(100 \%)$ & & \\
Ergonomi & Tinggi & $37(86,0 \%)$ & $6(14,0 \%)$ & $43(100 \%)$ & 0,278 & - \\
\hline Total & $78(81,2 \%)$ & $18(18,8 \%)$ & $96(100 \%)$ & & \\
\hline
\end{tabular}


Responden yang mengalami keluhan muskuloskeletal tangan dan pergelangan tangan kiri terbanyak terdapat pada tingkat risiko ergonomi sedang yaitu sebanyak 12 responden atau $22,6 \%$, selanjutnya responden yang tidak mengalami keluhan muskuloskeletal terbanyak juga terdapat pada tingkat risiko ergonomi sedang yaitu sebanyak 41 responden atau $77,4 \%$.

Tabel 9. Tabel Silang Risiko Ergonomi dengan Keluhan pada Bahu Kanan

\begin{tabular}{|c|c|c|c|c|c|c|}
\hline \multirow{2}{*}{\multicolumn{2}{|c|}{ Variabel }} & \multicolumn{2}{|c|}{ Keluhan pada Bahu Kanan } & \multirow{2}{*}{ Total } & \multirow{3}{*}{$\mathbf{p}$} & \\
\hline & & Tidak Ada Keluhan & Ada Keluhan & & & \\
\hline & Rendah & $46(78,0 \%)$ & $13(22,0 \%)$ & 59 (100\%) & & \\
\hline Risiko Ergonomi & $\begin{array}{c}\text { Sedang } \\
\text { Tinggi }\end{array}$ & $\begin{array}{l}12(63,2 \%) \\
12(77,8 \%)\end{array}$ & $\begin{array}{l}7(36,8 \%) \\
6(22,2 \%)\end{array}$ & $\begin{array}{l}19(100 \%) \\
18(100 \%)\end{array}$ & 0,362 & \\
\hline Total & & $67(69,8 \%)$ & $29(30,2 \%)$ & $96(100 \%)$ & & \\
\hline
\end{tabular}

Berdasarkan tabel diatas didapatkan hasil, responden yang mengalami keluhan muskuloskeletal bahu kanan terbanyak terdapat pada tingkat risiko ergonomi rendah yaitu sebanyak 13 responden atau $22 \%$, selanjutnya responden yang tidak mengalami keluhan muskuloskeletal terbanyak juga terdapat pada tingkat risiko ergonomi rendah yaitu sebanyak 46 responden atau $78 \%$.

Tabel 10. Tabel Silang Risiko Ergonomi dengan Keluhan pada Bahu Kiri

\begin{tabular}{ccccccc}
\hline \multicolumn{2}{c}{ Variabel } & \multicolumn{2}{c}{ Keluhan pada Bahu Kiri } & \multirow{2}{*}{ Total } & p & rs \\
\cline { 2 - 5 } & Tidak Ada Keluhan & Ada Keluhan & & & \\
\hline Risiko & Rendah & $59(85,5 \%)$ & $10(14,5 \%)$ & $69(100 \%)$ & & \\
Ergonomi & Sedang & $19(70,4 \%)$ & $8(29,6 \%)$ & $27(100 \%)$ & 0,156 & - \\
\hline Total & $78(81,2 \%)$ & $18(18,8 \%)$ & $96(100 \%)$ & & \\
\hline
\end{tabular}

Berdasarkan tabel diatas didapatkan hasil, responden yang mengalami keluhan muskuloskeletal bahu kiri terbanyak terdapat pada tingkat risiko ergonomi rendah yaitu sebanyak 10 responden atau $14,5 \%$, selanjutnya responden yang tidak mengalami keluhan muskuloskeletal terbanyak juga terdapat pada tingkat risiko ergonomi rendah yaitu sebanyak 59 responden atau $85,5 \%$.

Tabel 11. Tabel Silang Risiko Ergonomi dengan Keluhan pada Lengan Atas Kanan

\begin{tabular}{|c|c|c|c|c|c|c|}
\hline \multirow{2}{*}{\multicolumn{2}{|c|}{ Variabel }} & \multicolumn{2}{|c|}{ Keluhan pada Lengan Atas Kanan } & \multirow{2}{*}{ Total } & \multirow[b]{2}{*}{$\mathbf{p}$} & \multirow{2}{*}{ rs } \\
\hline & & Tidak Ada Keluhan & Ada Keluhan & & & \\
\hline \multirow{3}{*}{ Risiko Ergonomi } & Rendah & $46(78,0 \%)$ & $13(22,0 \%)$ & $59(100 \%)$ & \multirow{4}{*}{0,133} & \\
\hline & Sedang & $12(63,2 \%)$ & $7(36,8 \%)$ & 19 (100\%) & & \\
\hline & Tinggi & $10(55,6 \%)$ & $8(44,4 \%)$ & $18(100 \%)$ & & \\
\hline Total & & $68(70,8 \%)$ & $28(29,2 \%)$ & $96(100 \%)$ & & \\
\hline
\end{tabular}

Berdasarkan tabel diatas didapatkan hasil, responden yang mengalami keluhan muskuloskeletal lengan atas kanan terbanyak terdapat pada tingkat risiko ergonomi rendah yaitu sebanyak 13 responden atau $22 \%$, selanjutnya responden yang tidak mengalami keluhan muskuloskeletal terbanyak juga terdapat pada tingkat risiko ergonomi rendah yaitu sebanyak 46 responden atau $78 \%$.

Tabel 12. Tabel Silang Risiko Ergonomi dengan Keluhan pada Lengan Atas Kiri

\begin{tabular}{ccccccc}
\hline \multicolumn{2}{c}{ Variabel } & \multicolumn{2}{c}{ Keluhan pada Lengan Atas Kiri } & Total & p & rs \\
\cline { 2 - 4 } & Tidak Ada Keluhan & Ada Keluhan & & & \\
\hline Risiko & Rendah & $57(82,6 \%)$ & $12(17,4 \%)$ & $69(100 \%)$ & & \\
Ergonomi & Sedang & $19(70,4 \%)$ & $8(29,6 \%)$ & $27(100 \%)$ & 0,295 & - \\
\hline Total & $76(79,2 \%)$ & $20(20,8 \%)$ & $96(100 \%)$ & & \\
\hline
\end{tabular}

Berdasarkan tabel diatas didapatkan hasil, responden yang mengalami keluhan muskuloskeletal lengan atas kiri terbanyak terdapat pada tingkat risiko ergonomi rendah yaitu sebanyak 12 responden atau $17,4 \%$, selanjutnya responden yang tidak mengalami keluhan muskuloskeletal terbanyak juga terdapat pada tingkat risiko ergonomi rendah yaitu sebanyak 57 responden atau $82,6 \%$.

Tabel 13. Tabel Silang Risiko Ergonomi dengan Keluhan pada Siku Kanan

\begin{tabular}{|c|c|c|c|c|c|c|}
\hline \multirow{2}{*}{\multicolumn{2}{|c|}{ Variabel }} & \multicolumn{2}{|c|}{ Keluhan pada Siku Kanan } & \multirow{2}{*}{ Total } & \multirow{2}{*}{$\mathbf{p}$} & \multirow{2}{*}{ rs } \\
\hline & & Tidak Ada Keluhan & Ada Keluhan & & & \\
\hline \multirow{3}{*}{ Risiko Ergonomi } & Rendah & $45(78,9 \%)$ & $12(21,1 \%)$ & $57(100 \%)$ & \multirow{4}{*}{0,069} & \\
\hline & Sedang & $11(52,4 \%)$ & $10(47,6 \%)$ & 21 (100\%) & & \\
\hline & Tinggi & $13(72,2 \%)$ & $5(27,8 \%)$ & $18(100 \%)$ & & - \\
\hline Total & & $69(71,9 \%)$ & $27(28,1 \%)$ & $96(100 \%)$ & & \\
\hline
\end{tabular}

Berdasarkan tabel 13 didapatkan hasil, responden yang mengalami keluhan muskuloskeletal siku kanan terbanyak terdapat pada tingkat risiko ergonomi rendah yaitu sebanyak 12 responden atau $21,1 \%$, selanjutnya responden yang tidak mengalami keluhan muskuloskeletal terbanyak juga terdapat pada tingkat risiko ergonomi rendah yaitu sebanyak 45 responden atau $78,9 \%$. 
Tabel 14. Tabel Silang Risiko Ergonomi dengan Keluhan pada Siku Kiri

\begin{tabular}{|c|c|c|c|c|c|c|}
\hline \multicolumn{2}{|l|}{ Variabel } & \multicolumn{2}{|c|}{ Keluhan pada Siku Kiri } & \multirow{2}{*}{ Total } & \multirow{2}{*}{$\mathbf{p}$} & \multirow{2}{*}{ rs } \\
\hline & & Tidak Ada Keluhan & Ada Keluhan & & & \\
\hline \multirow[b]{2}{*}{ Risiko Ergonomi } & Rendah & $45(89,9 \%)$ & $8(15,1 \%)$ & $53(100 \%)$ & \multirow{3}{*}{0,689} & \multirow{3}{*}{ - } \\
\hline & Sedang & $25(80,6 \%)$ & $6(19,4 \%)$ & $31(100 \%)$ & & \\
\hline Total & & $79(82,3 \%)$ & $17(17,7 \%)$ & $96(100 \%)$ & & \\
\hline
\end{tabular}

Berdasarkan tabel 14 didapatkan hasil, responden yang mengalami keluhan muskuloskeletal siku kiri terbanyak terdapat pada tingkat risiko ergonomi rendah yaitu sebanyak 8 responden atau 15,1\%, selanjutnya responden yang tidak mengalami keluhan muskuloskeletal terbanyak juga terdapat pada tingkat risiko ergonomi rendah yaitu sebanyak 45 responden atau $89,9 \%$.

\section{DISKUSI \\ Karakteristik Responden}

Penelitian ini dilakukan di tempat kerja pengrajin ukiran kayu di kecamatan Gianyar dan Sukawati, Gianyar. Pada penelitian ini karakteristik responden yaitu berdasarkan umur menunjukkan bahwa responden terbanyak yaitu pada rentangan umur $35-47$ tahun yaitu sebanyak 63 responden atau $65,6 \%$ dan pada rentangan umur $48-60$ tahun jumlah responden yaitu 33 responden atau $34,4 \%$. Distribusi responden berdasarkan lama kerja menunjukkan bahwa responden dengan lama kerja 6 jam sebanyak 1 responden atau 1,1\%, lama kerja 7 jam sebanyak 13 responden atau $13,5 \%$ dan lama kerja 8 jam sebanyak 82 responden atau $85,4 \%$. Masa kerja responden yaitu dengan masa kerja 1-25 tahun sebanyak 54 responden $56,2 \%$ dan masa kerja lebih dari 25 tahun yaitu sebanyak 42 responden atau $43,8 \%$, di mana total keseluruhan responden berjumlah 96 responden sesuai dengan rumus besar sampel yang dicari.

Faktor risiko ergonomi saat bekerja pada penelitian ini diukur dengan BRIEF Survey. Berdasarkan hasil analisa, faktor risiko ergonomi saat bekerja mendapatkan hasil yakni risiko rendah, sedang dan tinggi. Pada penelitian ini punggung memiliki risiko ergonomi tinggi yang paling banyak yaitu sebanyak 48 responden atau $50 \%$. Risiko ergonomi yang tidak sesuai kriteria BRIEF Survey yang paling banyak yaitu pada postur kerja, durasi dan frekuensi. Umumnya, postur kerja pada pengrajin cenderung dalam posisi duduk, membungkuk dan sedikit menunduk yang dilakukan dalam jangka waktu yang lama dan berulang-ulang. Selain itu, saat melakukan pekerjaannya tangan pengrajin melakukan gerakan yang repetitif dan selalu memegang alat. Postur kerja yang menjauhi posisi normal tubuh ini, lebih banyak diakibatkan oleh tidak sesuainya antara dimensi alat dan stasiun kerja dengan ukuran tubuh manusia. Kondisi tersebut dapat menyebabkan postur paksa atau janggal saat melakukan pekerjaannya ${ }^{14}$.

Berdasarkan distribusi keluhan muskuloskeletal yang diukur dengan CMDQ pada penelitian ini, keluhan yang paling sering timbul pada pengrajin ukiran kayu adalah keluhan pada punggung bawah yaitu sebanyak 67 responden atau $69,8 \%$ dan leher sebanyak 43 responden atau $44,8 \%$. Hal ini sejalan dengan penelitian (Wiratma dan Handari Adiputra, 2016) mengenai gambaran keluhan muskuloskeletal pada pengrajin ukiran kayu ${ }^{9}$. Keluhan muskuloskeletal pada pengrajin ini disebabkan oleh kontraksi otot yang berlebihan (overuse). Overuse pada suatu jaringan ini akan menimbulkan rasa sakit, ketidaknyamanan atau kelelahan lokal yang sering disebut dengan keluhan muskuloskeletal ${ }^{15}$.

\section{Hubungan Faktor Risiko Ergonomi Saat Bekerja dengan Keluhan Muskuloskeletal Leher}

Keluhan muskuloskeletal pada pengrajin ukiran kayu di Gianyar akibat dari postur kerja yang statis, cenderung membungkuk dan menunduk. Postur kerja yang statis ini dapat menyebabkan penempatan beban pada otot dan tendon. Postur tersebut dapat menimbulkan keluhan pada otot $^{3}$. Selain itu, apabila dilakukan berulang-ulang dengan durasi yang cukup lama serta beban kerja yang tinggi menyebabkan waktu istirahat pekerja yang hampir tidak ada sehingga menimbulkan keluhan muskuloskeletal ${ }^{16}$.

Hasil analisis data dengan chi-square test diperoleh $p=0,035(<0,05)$ yang artinya terdapat hubungan yang signifikan antara faktor risiko ergonomi saat bekerja dengan keluhan muskuloskeletal leher pada pengrajin ukiran kayu di Gianyar. Berdasarkan uji spearman's rho didapatkan hasil yaitu hubungan bernilai (+) yang berarti peningkatan pada faktor risiko ergonomi saat bekerja akan diikuti dengan peningkatan keluhan muskuloskeletal leher. Nilai koefisien korelasi (rs) sebesar 0,247, sehingga dapat disimpulkan hubungan yang lemah antara faktor risiko ergonomi saat bekerja dengan keluhan muskuloskeletal leher pada pengrajin ukiran kayu di Gianyar.

Dari 96 postur yang telah diteliti didapatkan hal-hal, seperti postur leher saat bekerja yang tidak ergonomis. Postur leher pada pengrajin cenderung menunduk dan miring dikarenakan kayu yang akan diukir tersebut berada di lantai sehingga pengrajin lebih nyaman dalam melakukan postur tersebut saat bekerja. Postur kerja statis yang cenderung menunduk dan miring dalam jangka waktu yang lama akan menyebabkan kontraksi terus menerus pada otot leher (overuse). Hal ini didukung oleh penelitian (Awal, et al., 2016) yang menyebutkan bahwa postur kerja statis selama beberapa menit bahkan jam tanpa istirahat dapat mengakibatkan keluhan atau rasa sakit pada leher ${ }^{17}$. (Belayana, et al., 2014) juga menyebutkan bahwa faktor yang menyebabkan terjadinya keluhan pada leher pengrajin ukiran kayu adalah sikap kerja yang salah, dimana pada penelitian ini terdapat sebanyak $80 \%$ pengerajin ukiran kayu di Banjar Cebaang mengalami keluhan pada leher ${ }^{18}$.

Postur kerja pada leher yang tidak ergonomis seperti menunduk dapat menyebabkan terjadinya ketegangan pada otot leher yang berlebih. Hal ini menyebabkan tubuh melakukan kompensasi untuk menjaga keseimbangan dengan posisi kepala kearah anterior dari trunk sehingga menimbulkan terjadinya forward head posture. Forward head posture yang terjadi karena adanya ketidakseimbangan kerja dan aktivasi otot yang tepat (muscle imbalance) ini umumnya menyebabkan pemendekan pada otot ekstensor leher dimana otot semispinalis capitis dan levator scapula yang paling besar mengalami tekanan dan menyebabkan kelemahan pada otot fleksor leher yaitu otot sternocleidomastoideus, longus colli, and scalenus anterior. Apabila postur tersebut terjadi dalam jangka waktu yang 
lama maka dapat memicu stres dinamis dan nyeri pada leher dan bahu, yang menyebabkan ketidakseimbangan pada kekuatan dan fleksibilitas otot $19,20,21$.

\section{Hubungan Faktor Risiko Ergonomi Saat Bekerja dengan Keluhan Muskuloskeletal Punggung}

Hasil analisis data dengan chi-square test diperoleh $p=0,018(<0,05)$ yang artinya terdapat hubungan yang signifikan antara faktor risiko ergonomi saat bekerja dengan keluhan muskuloskeletal punggung atas pada pengrajin ukiran kayu di Gianyar. Berdasarkan uji spearman's rho didapatkan hasil yaitu hubungan bernilai (+) yang berarti peningkatan pada faktor risiko ergonomi saat bekerja akan diikuti dengan peningkatan keluhan muskuloskeletal punggung atas. Nilai koefisien korelasi (rs) sebesar 0,246, sehingga dapat disimpulkan hubungan yang lemah antara faktor risiko ergonomi saat bekerja dengan keluhan muskuloskeletal punggung atas pada pengrajin ukiran kayu di Gianyar.

Penelitian ini serupa dengan penelitian Nino, et al., 2018 yang mengatakan bahwa terdapat hubungan antara postur punggung dengan keluhan muskuloskeletal pada punggung pada pekerja pabrik pemotongan kayu, dimana sebanyak 73,3\% pekerja yang mengalami keluhan. Hal ini dikarenakan pada posisi membungkuk, tubuh berusaha menjaga kestabilan tubuh sehingga tulang punggung bergerak ke sisi depan tubuh dan menyebabkan otot punggung berkontraksi. Selain itu, otot-otot punggung juga akan bekerja keras menahan beban anggota gerak atas yang sedang melakukan pekerjaannya ${ }^{22}$. Keluhan muskuloskeletal pada punggung atas ini juga dapat disebabkan oleh keluhan pada leher dan punggung bawah akibat aktivitas atau postur tubuh yang kurang baik sehingga menimbulkan terjadinya spasme 23 .

Hasil analisis data dengan chi-square test diperoleh $p=0,016(<0,05)$ yang artinya terdapat hubungan yang signifikan antara faktor risiko ergonomi saat bekerja dengan keluhan muskuloskeletal punggung bawah pada pengrajin ukiran kayu di Gianyar. Berdasarkan uji spearman's rho didapatkan hasil yaitu hubungan bernilai $(+)$ yang berarti peningkatan pada faktor risiko ergonomi saat bekerja akan diikuti dengan peningkatan keluhan muskuloskeletal punggung bawah. Nilai koefisien korelasi (rs) sebesar 0,284, sehingga dapat disimpulkan hubungan yang lemah antara faktor risiko ergonomi saat bekerja dengan keluhan muskuloskeletal punggung bawah pada pengrajin ukiran kayu di Gianyar.

Hasil penelitian ini serupa dengan penelitian (Aeni and Awaludin, 2017) mengenai hubungan sikap kerja duduk dengan keluhan nyeri punggung bawah yang menyatakan bahwa terdapat hubungan yang signifikan ${ }^{24}$. Keluhan ini disebabkan oleh posisi kerja duduk yang berisiko, duduk lama dengan posisi yang salah akan menyebabkan otot-otot punggung bawah menjadi tegang dan dapat merusak jaringan lunak sekitarnya. Penelitian sebelumnya pada tahun 2014 oleh Umami et al. juga mendapatkan hasil yang serupa dengan penelitian ini. Mereka berpendapat bahwa postur tubuh yang baik dapat mencegah terjadinya keluhan nyeri punggung bawah. Pada penelitian ini dari 93,3\% pekerja batik tulis yang mengalami keluhan punggung bawah sebagian besar pekerja batik tulis bekerja dengan sikap duduk yang tidak ergonomis ${ }^{25}$.

Berdasarkan BRIEF Survey pengrajin cenderung bekerja dengan postur yang tidak ergonomis, dimana frekuensi dari postur kerja yang tidak ergonomis yaitu $\geq 2$ menit dan dalam durasi yang lama. Postur kerja pengrajin yang tidak ergonomis ini, dimana pengrajin cenderung membungkuk dan tanpa sandaran dapat meningkatkan risiko timbulnya keluhan muskuloskeletal pada punggung. Beberapa pengrajin juga melakukan postur kerja miring pada punggungnya. Pada saat bekerja dengan sikap duduk membungkuk kurva lordosis pada lumbal akan hilang. Hal tersebut menyebabkan dapat merusak nukleus pulposus terutama di daerah L4-L5 dan L5-S1. Sikap kerja membungkuk menyebabkan overstretch dan annulus fibrosus posterior melemah sehingga tidak dapat menahan nukleus pulposus menonjol ke belakang. Selain itu sikap kerja membungkuk dapat mengakibatkan stress pada otot-otot tulang belakang yaitu otot-otot erector spinalis (sacrospinal, quadratus lumborum, latissimus dorsi dan multifidus) ${ }^{21}$.

Posisi duduk yang tidak ergonomis memungkinkan terjadinya tekanan pada jaringan pada tulang punggung, sehingga dapat menimbulkan nyeri. Jika hal tersebut dilakukan terus menerus dalam jangka waktu lama dapat menimbulkan terjadinya low back pain, dimana low back pain yang terjadi akibat sikap kerja yang tidak ergonomis yaitu low back pain non spesifik ${ }^{26}$. Terjadinya low back pain dapat disebabkan oleh ketegangan otot (strain) dan keregangan pada ligamen tulang belakang (sprain) akibat postur duduk membungkuk, dimana menyebabkan otot perut (abdominal) melembek dan tulang belakang akan melengkung. Postur janggal tersebut menyebabkan gangguan biomekanik vertebra lumbal akibat perubahan titik berat badan sehingga dapat menimbulkan nyeri27,28. Postur kerja yang janggal atau tidak ergonomis juga dapat menyebabkan beban postural yang berat dan apabila hal tersebut terjadi dalam jangka waktu yang lama, maka akan menimbulkan postural strain yang merupakan beban mekanik statis bagi otot. Kondisi tersebut menyebabkan aliran darah ke otot berkurang sehingga terjadi gangguan keseimbangan kimia di otot dan menimbulkan kelelahan pada otot ${ }^{29}$.

\section{Hubungan Faktor Risiko Ergonomi Saat Bekerja dengan Keluhan Muskuloskeletal Tangan dan Pergelangan Tangan}

Pada penelitian ini hubungan antara faktor risiko ergonomi saat bekerja dengan keluhan muskuloskeletal tangan dan pergelangan tangan dibedakan menjadi tangan dan pergelangan tangan kanan dan kiri. Hasil analisis data dengan chi-square test diperoleh $\mathrm{p}=0,001(<0,05)$ yang artinya terdapat hubungan yang signifikan antara faktor risiko ergonomi saat bekerja dengan keluhan muskuloskeletal tangan dan pergelangan tangan kanan pada pengrajin ukiran kayu di Gianyar. Berdasarkan uji spearman's rho didapatkan hasil yaitu hubungan bernilai (+) yang berarti peningkatan pada faktor risiko ergonomi saat bekerja akan diikuti dengan peningkatan keluhan muskuloskeletal tangan dan pergelangan tangan. Nilai koefisien korelasi (rs) sebesar 0,396, sehingga dapat disimpulkan hubungan yang lemah antara faktor risiko ergonomi saat bekerja dengan keluhan muskuloskeletal tangan dan pergelangan tangan kanan pada pengrajin ukiran kayu di Gianyar. 
Hal ini didukung oleh penelitian (Sistarina, et al., 2017) yang menyatakan bahwa terdapat hubungan antara faktor risiko pajanan ergonomi dengan keluhan muskuloskeletal pada daerah tangan dan pergelangan tangan kanan. Hal tersebut dikarenakan oleh gerakan tangan yang berulang-ulang sehingga menimbulkan keluhan muskuloskeletal ${ }^{30}$. (Agustin, et al., 2013) juga menyebutkan bahwa terdapat hubungan yang signifikan antara sikap kerja dengan kejadian sindrom terowongan karpal (45,5\%) pada pembatik. Postur pergelangan tangan kanan pengrajin saat bekerja cenderung dalam posisi power grip dan fleksi-ekstensi yang berlebihan dilakukan berulang-ulang dan dalam jangka waktu yang lama serta dikombinasikan dengan memegang alat. Saat melakukan pekerjaannya pengrajin menggunakan kedua tangannya, tangan kanan digunakan untuk memegang palu dan tangan kiri digunakan untuk memegang pahat. Pekerjaan yang monoton dan gerakan yang berulang tersebut akan menyebabkan pembengkakan sarung tendon sehingga menimbulkan tekanan pada tendon pergelangan tangan. Selain itu, gerakan pergelangan tangan tersebut dapat mengakibatkan penebalan pada ligamentum karpi transversum sehingga terjadi penyempitan terowongan karpal dan dapat menghimpit saraf. Hal tersebut menyebabkan terjadinya carpal tunnel syndrome ${ }^{31}$.

Hasil analisis data dengan chi-square test diperoleh $p=0,278(>0,05)$ yang artinya tidak terdapat hubungan antara faktor risiko ergonomi saat bekerja dengan keluhan muskuloskeletal pergelangan tangan kiri pada pengrajin ukiran kayu di Gianyar. Hasil ini serupa dengan penelitian Wiyatno, 2011 yang menyebutkan bahwa tidak terdapat hubungan yang signifikan antara sikap kerja dengan keluhan muskuloskeletal tangan. Hal tersebut dikarenakan tangan saat melakukan pekerjaan tidak diberikan beban berlebih, sehingga kemungkinan untuk mengalami gangguan muskuloskeletal tangan sangat kecil23.

Pada pengrajin ukiran kayu, tangan dan pergelangan tangan kiri saat bekerja memegang alat yaitu pahat dengan posisi pinch grip. Tangan dan pergelangan tangan kiri pada pengrajin lebih banyak digunakan untuk menahan atau menyeimbangkan alat pahat. Hal tersebut menyebabkan beban yang diterima oleh tangan dan pergelangan tangan kiri pengrajin tidak besar. Walaupun begitu, tangan dan pergelangan tangan kiri ini tidak memiliki risiko ergonomi rendah yang artinya sebagian besar pengrajin bekerja dengan posisi tangan dan pergelangan tangan kiri yang tidak ergonomis. Apabila hal tersebut dibiarkan dalam waktu yang lama maka tingkat risiko ergonomi dapat mempengaruhi keluhan muskuloskeletal ${ }^{32}$.

\section{Hubungan Faktor Risiko Ergonomi Saat Bekerja dengan Keluhan Muskuloskeletal Bahu}

Pada penelitian ini hubungan antara faktor risiko ergonomi saat bekerja dengan keluhan muskuloskeletal bahu dibedakan menjadi bahu kanan dan kiri. Hasil analisis data dengan chi-square test diperoleh $p=0,362(>0,05)$ pada bahu kanan dan $p=0,156(>0,05)$ pada bahu kiri yang artinya tidak terdapat hubungan yang signifikan antara faktor risiko ergonomi saat bekerja dengan keluhan muskuloskeletal baik pada bahu kanan dan kiri pada pengrajin ukiran kayu di Gianyar.

Hasil ini bertolak belakang dengan penelitian (Abdillah, 2015) yang menyebutkan terdapat hubungan antara sikap kerja dengan kejadian rotator cuff injury ${ }^{33}$. Namun, hasil penelitian ini serupa dengan penelitian (Ramadhiani, et al., 2017) yang menyebutkan tidak ada hubungan antara sudut bahu membatik dengan keluhan nyeri bahu. Hal tersebut dikarenakan lebih banyak pekerja yang membentuk sudut bahu yang normal dibanding pekerja yang membentuk postur bahu yang tidak normal pada saat melakukan pekerjaannya ${ }^{34}$. Pada pengrajin ukiran kayu, umumnya melakukan pekerjaannya dengan posisi bahu yang normal tetapi ada juga beberapa pengrajin yang melakukan posisi kerja tidak ergonomis pada bahu yaitu contohnya dengan bahu terangkat dan membentuk sudut bahu $45^{\circ}$. Posisi kerja yang tidak ergonomis ini dilakukan dalam jangka waktu yang lama, namun tidak ada pembebanan pada bahu pengrajin.

Berdasarkan hasil analisis hubungan antara faktor risiko ergonomi saat bekerja dengan keluhan muskuloskeletal lengan atas kanan dan kiri. Hasil analisis data dengan chi-square test diperoleh $p=0,133(>0,05)$ pada lengan atas kanan dan $p=0,295(>0,05)$ pada lengan atas kiri yang artinya tidak terdapat hubungan yang signifikan antara faktor risiko ergonomi saat bekerja dengan keluhan muskuloskeletal baik pada lengan atas kanan dan kiri pada pengrajin ukiran kayu di Gianyar.

Pada penelitian ini, tidak terdapatnya hubungan antara faktor risiko ergonomi dengan keluhan muskuloskeletal lengan atas diakibatkan oleh tidak adanya pembebanan yang terjadi pada lengan atas pengrajin baik kanan ataupun kiri. Selain itu postur kerja yang dapat menimbulkan keluhan muskuloskeletal pada lengan atas pengrajin sebagian besar risiko ergonominya rendah. Hal tersebut membuktikan bahwa apabila penerapan ergonomi dilakukan saat bekerja maka dapat mengurangi risiko terjadinya keluhan muskuloskeletal. Sesuai dengan pernyataan (Tarwaka et al., 2004), bahwa penerapan ergonomi di segala bidang kegiatan adalah suatu keharusan. Apabila ergonomi tidak diterpkan, maka akan mengakibatkan ketidaknyamanan, biaya tinggi, kecelakaan dan penyakit akibat kerja meningkat, performansi menurun yang berakibat kepada penurunan efisiensi dan daya kerja ${ }^{1}$.

\section{Hubungan Faktor Risiko Ergonomi Saat Bekerja dengan Keluhan Muskuloskeletal Siku}

Berdasarkan hasil analisa tentang hubungan antara faktor risiko ergonomi saat bekerja dengan keluhan muskuloskeletal siku dibedakan menjadi siku kanan dan kiri. Hasil analisis data dengan chi-square test diperoleh $\mathrm{p}=0,069(>0,05)$ pada siku kanan dan $\mathrm{p}=0,689(>0,05)$ pada siku kiri yang artinya tidak terdapat hubungan yang signifikan antara faktor risiko ergonomi saat bekerja dengan keluhan muskuloskeletal baik pada siku kanan dan kiri pada pengrajin ukiran kayu di Gianyar.

Penelitian ini didukung oleh penelitian (Wiyatno, 2011) yang menyebutkan bahwa tidak terdapat hubungan yang signifikan antara sikap kerja dengan keluhan muskuloskeletal siku (56\% mengalami keluhan siku) pada buruh panggul. Hal tersebut dikarenakan posisi siku pekerja pada saat melakukan pekerjaannya tidak selalu berubah dari posisi normal. Selain itu, siku juga tidak mendapatkan beban berlebih, sehingga kemungkinan besar untuk mengalami gangguan muskuloskeletal siku sangat kecil23. 
Pada pengrajin ukiran kayu umumnya melakukan pekerjaannya dengan risiko ergonomi rendah pada siku, baik siku kanan dan kiri. Hal ini yang menyebabkan tidak adanya hubungan antara risiko ergonomi dengan keluhan muskuloskeletal siku pada pengrajin ukiran kayu. Selain itu, tidak adanya pembebanan pada siku juga mempengaruhi hal tersebut. Hal ini sesuai dengan pernyataan (Tarwaka, et al., 2004) bahwa faktor sikap kerja yang ergonomis dapat mencegah terjadinya keluhan muskuloskeletal ${ }^{1}$.

\section{SIMPULAN}

Berdasarkan hasil penelitian dapat disimpulkan yaitu terdapat hubungan antara faktor risiko ergonomi saat bekerja dengan keluhan muskuloskeletal leher, punggung atas, punggung bawah serta tangan dan pergelangan tangan kanan pada pengrajin ukiran kayu di Gianyar.

\section{DAFTAR PUSTAKA}

1. Tarwaka, Bakri, S. H. and Sudiajeng, L. Ergonomi untuk Keselamatan, Kesehatan Kerja dan Produktivitas. 1 ed. Surakarta: UNIBA Press. 2004.

2. Amin, N. A. et al. Relationship between Psychosocial Risk Factors and Work-Related Musculoskeletal Disorders. Annals of Occupational and Environmental Medicine, 2004; 26(1), pp. 1-9.

3. Bukhori, E. Hubungan Faktor Risiko Pekerjaan dengan Terjadinya Keluhan Musculoskeletal Disorder (MSDs) pada Tukang Angkat Beban Penambang Emas di Kecamatan Cilograng Kabupaten Lebak Tahun 2010. Skripsi. 2010.

4. Mayasari, D. and Saftarina, F. Ergonomi sebagai Upaya Pencegahan Musculoskeletal Disorders pada Pekerja. JK Unila, 1(2), 2016; pp. 369-379.

5. Wardaningsih, I. Pengaruh Sikap Kerja Duduk Pada Kursi Kerja yang Tidak Ergonomis terhadap Keluhan Otot otot Skeletal Bagian Mesin Cucuk di PT Iskandat Indah Printing Textile Surakarta. Skripsi. 2010.

6. Santosa, A. and Ariska, D. K. Faktor-Faktor yang Berhubungan dengan Kejadian Musculoskeletal Disorders pada Pekerja Batik di Kecamatan Sokaraja Banyumas. MEDISAINS: Jurnal IImiah IImu-ilmu Kesehatan, 2018; 16(1), pp. 42-46.

7. Jalajuwita, R. N. and Paskarini, I. Hubungan Posisi Kerja Dengan Keluhan Muskuloskeletal Pada Unit Pengelasan PT. X Bekasi. The Indonesian Journal of Occupational Safety and Health, Volume 4 , 2015; pp. 33-42.

8. Ulfah, N., Harwanti, S. and Nurcahyo, J. Sikap Kerja dan Risiko Musculoskeletal Disorders pada Pekerja Laundry. Jurnal Kesehatan Masyarakat Nasional, 8(7), 2014; pp. 313-318.

9. Wiratma, I. K. A. and Handari Adiputra, L. M. I. S. Gambaran Keluhan Muskuloskeletal Pada Perajin Ukiran Kayu di Kecamatan Manggis Kabupaten Karangasem. E-Jurnal Medika. 2016

10. Putri, P. D. W. and Griadhi, I. P. A. Perbaikan Stasiun Kerja Menurunkan Aktivitas Listrik Otot dan Keluhan Muskuloskeletal pada Perajin Ukir Kayu di Desa Batuan Gianyar Bali. E-Jurnal Medika Udayana, 4(8). 2015.

11. Humantech. Applied Ergonomics Training Manual: Prepared for Procter and Gamble Inc.. Barkeley Valey: s.n. 1995.

12. Suriatmini, S. Tinjauan Faktor Risiko Ergonomi Terhadap Keluhan Muskuloskeletal Pada Aktivitas Manual Handling Pada Pekerja di Bagian Produksi PTMI Tahun 2010. Tesis. 2011.

13. Web, C. U. E. Cornell Musculoskeletal Discomfort Questionnaires (CDMQ). [Online] Available at: http://ergo.human.cornell.edu/ahmsquest.html. 1999. [Accessed 17 November 2018].

14. Supriyanto. Perancangan Postur Kerja pada Pekerja Bagian Pencucian dan Penggilingan Kedelai dengan Pendekatan Rapid Entire Body Assessment (REBA) untuk Mengurangi Risiko Musculoskeletal Disorders (MSDs). Skripsi. 2011.

15. Simoneau, S., St-Vincent, M. and Chicoine, D. Work-Related Musculoskeletal Disorders (WMSDs). Saint Leonard, Quebec: IRSST and A.S.P Metal-Electrique. 1996.

16. Puspita, D., Suroto and Kurniawan, B.Analisis Postur Kerja Terhadap Keluhan Musculoskeletal Disorders (MSDs) Pada Pekerja Mekanik Bengkel Sepeda Motor X Semarang. Jurnal Kesehatan Masyarakat (e-Journal), 2017; 5(1), pp. 126-133.

17. Awal, G. S. D., Arief, a. M. and Utami, D.Hubungan Sikap Kerja Duduk dengan Keluhan Nyeri Leher pada Pekerja Menggunakan Rapid Upper Limbassessment (RULA) di PT Tunas Alfin TBK. Repository Universitas Esa Unggul, 20 September. 2016.

18. Belayana, I. B. G. B., Darmadi, I. G. W. and Mahayana, I. M. B. Hubungan Faktor Waktu Kerja, Waktu Istirahat dan Sikap Kerja terhadap Keluhan Nyeri Tengkuk pada Pengrajin Ukiran Kayu. Jurnal Kesehatan Lingkungan, 2014; Mei, 4(1), pp. 6-15.

19. Nejati, P. The Study of Correlation Between Forward Head Posture and Neck Pain in Iranian Office Workers. International Journal of Occupational Medicine and Environmental Health, 2005; 28(26), pp. 1-7.

20. Lee, M., Park, S. and Kim, J. Effects of Neck Exercise on High-School Students' Neck-Shoulder Posture. Journal of Physical Therapy Science, 2013; 25(5), pp. 571-574.

21. Neumann, D. A. Kinesiology of the Musculoskeletal System: Foundations of Rehabilitation. Second Edition ed. United States: Elsevier. 2010.

22. Nino, B. P., Widjasena, B. and Ekawati. Hubungan Tingkat Risiko Ergonomi dan Beban Angkut Terhadap Keluhan Musculoskeletal Disorders (MSDs) pada Pabrik Pemotongan Kayu X Mranggen, Demak. Jurnal Kesehatan Masyarakat (e-journal), 2018; 6(5), pp. 494-501.

23. Wiyatno, T. H. Hubungan antara Beban Kerja dan Sikap Kerja dengan Keluhan Muskuloskeletal pada Buruh Panggul di Kawasan Industri Candi Kota Semarang. Skripsi. 2011.

24. Aeni, H. F. and Awaludin. Hubungan Sikap Kerja Duduk dengan Keluhan Nyeri Punggung Bawah Pada Pekerja yang Menggunakan Komputer. 2017; pp. 887-954. 
25. Umami, A. R., Hartanti, R. I. and Dewi, A. Hubungan antara Karakteristik Responden dan Sikap Kerja Duduk dengan Keluhan Nyeri Punggung Bawah (Low Back Pain) Pada Pekerja Batik Tulis. e-Jurnal Pustaka Kesehatan, 2014; 2(1), pp. 72-78.

26. Erick, P. and Derek, R. A Systematic Review of Musculoskeletal Disorders Among School Teachers. BMC Musculoskeletal Disorders, 2012; Volume 12, p. 260.

27. Irena, R. Hubungan Durasi Mengemudi dengan Keluhan Nyeri Punggung Bawah (Low Back Pain) pada Sopir Angkutan Umum (Superben) di Bangkinang Tahun 2016. PREPOTIF Jurnal Kesehatan Masyarakat, 2017; 1(1), pp. 50-57.

28. Sari, W. N. Hubungan antara Sikap Kerja Duduk dengan Keluhan Subyektif Nyeri Punggung Bawah pada Pekerja Pembuat Terasi di Tambak Rejo Tanjung Mas Semarang. Unnes Journal of Public Health, 2013; 2(2), pp. 1-9.

29. Pheasant, S. Ergonomics, Work and Health. London: Macmillan Academic Profesional Ltd. 1991.

30. Sistarina, G., Nataliningrum, R. D. M. and Djajasasmit, D. Hubungan Faktor Risiko Pajanan Ergonomi dengan Gangguan Muskuloskeletal pada Dokter Gigi. Repositori UNJANI. 2017.

31. Agustin, C. P. M., Mardiana and Budiono, I. Hubungan Masa Kerja dan Sikap Kerja dengan Kejadian Sindrom Karpal pada Pembatik CV. Pusaka Beruang Lasem. Unnes Journal of Public Health, 2013; 2(2), pp. 74-80.

32. Devi, T., Purba, I. G. and Lestari, M. Faktor Risiko Keluhan Musculoskeletal Disorders (Msds) Pada Aktivitas Pengangkutan Beras di PT Buyung Poetra Pangan Pegayut Ogan Ilir. Jurnal Ilmu Kesehatan Masyarakat, 2017; pp. 125-134.

33. Abdillah, O. Z. Hubungan antara Sikap Kerja dengan Kejadian Rotator Cuff Injury pada Montir Bengkel Mobil. Naskah Publikasi ed. Surakarta: Universitas Muhammadiyah Surakarta. 2015.

34. Ramadhiani, K. F., Widjasena, B. and Jayanti, S. Hubungan Durasi Kerja, Frekuensi Repetisi dan Sudut Bahu dengan Keluhan Nyeri Bahu pada Pekerja Batik Bagian Canting di Kampoeng Batik Laweyan Surakarta. Jurnal Kesehatan Masyarakat, 2017; 5(5), pp. 215-226. 